\title{
Serum sickness-like reaction associated with meropenem in a 3-year old child
}

\author{
Sara H Leo ${ }^{*}$, Edmond S Chan \\ From Canadian Society of Allergy and Clinical Immunology Annual Scientific Meeting 2010 \\ Victoria, Canada. 3-6 November 2010
}

\section{Background}

Serum sickness-like reactions are typically characterized by fever, arthralgia, rash, and other systemic symptoms within two weeks of antigen exposure. The most common inciting agents are non-protein drugs, most notably cefaclor. This report describes a 3-year old boy who developed a serum sickness-like reaction after receiving a course of meropenem.

\section{Materials and methods}

Laboratory investigations supporting a diagnosis of serum sickness-like reaction were performed.

\section{Results}

A 3 year old with a history of prematurity was treated with intravenous meropenem and vancomycin for a ventriculoperitoneal shunt infection and brain abscess. He developed fever, bilateral knee swelling and an erythematous maculopapular rash to his trunk and extremities on day 14 of meropenem and day 27 of vancomycin. During this time, he had elevated creatinine and $\mathrm{C}$ reactive protein, as well as eosinophilia and hematuria. Septic workup was negative, as were tests for autoimmunity. He also developed transient coagulopathy and pancytopenia, felt to be adverse effects of the antibiotics. He was eventually treated with 3 days of intravenous methylprednisolone, and his symptoms improved soon after. The total duration of serum sickness-like symptoms was about 2 weeks.

\section{Conclusions}

We believe this is the first description ever of serum sickness-like reaction to meropenem in a child. There are no other reports of serum sickness-like reactions to

\footnotetext{
* Correspondence: sleo@cw.bc.ca

Department of Pediatrics, Division of Allergy, University of British Columbia,

BC Children's Hospital, Vancouver, British Columbia, Canada, V6H 3V4
}

carbapenems (including meropenem and imipenem), other than a single case report of a 34-year old adult who had a serum sickness-like reaction to meropenem. [1].

Published: 4 November 2010

\section{Reference}

1. Ralph ED, John M, Rieder MJ, Bombassaro AM: Serum Sickness-like Reaction Possibly Associated with Meropenem Use. Clinical Infectious Diseases 2003, 36:149-151.

\section{doi:10.1186/1710-1492-6-S2-P31}

Cite this article as: Leo and Chan: Serum sickness-like reaction associated with meropenem in a 3-year old child. Allergy, Asthma \& Clinical Immunology 2010 6(Suppl 2):P31.
Submit your next manuscript to BioMed Central and take full advantage of:

- Convenient online submission

- Thorough peer review

- No space constraints or color figure charges

- Immediate publication on acceptance

- Inclusion in PubMed, CAS, Scopus and Google Scholar

- Research which is freely available for redistribution

\section{() Biomed Central}

